\title{
A RITMIKAI SZINKRONIZÁCIÓ KAPCSOLATA A FONOLÓGIAI TUDATOSSÁGGAL ÉS AZ OLVASÁSSAL ISKOLAKEZDŐ GYEREKEKNÉL
}

\author{
KERTÉSZ CSABA ${ }^{1,2}$ - F. FÖLDI RITA ${ }^{2}-$ HONBOLYGÓ FERENC ${ }^{3,4}$ \\ ${ }^{1}$ Eötvös Loránd Tudományegyetem Pedagógiai és Pszichológiai Kar \\ Pszichológiai Doktori Iskola \\ ${ }^{2}$ Károli Gáspár Református Egyetem, Pszichológiai Intézet \\ ${ }^{3}$ MTA Természettudományi Kutatóközpont Agyi Képalkotó Központ \\ ${ }^{4}$ Eötvös Loránd Tudományegyetem Pedagógiai és Pszichológiai Kar Pszichológiai Intézet \\ E-mail: kertesz.cs@gmail.com
}

Benyújtva: 2019. december 6. - Elfogadva: 2020. május 21.

\begin{abstract}
A ritmikai és a nyelvi, illetve olvasási képességek közötti kapcsolatot a gyakorlati megfigyeléseken túl számos kutatás eredménye látszik alátámasztani, ugyanakkor a magyar anyanyelvú gyerekeket vizsgáló munkák száma ez idáig csekély. 39 tipikus elsố osztályos (6-7 éves) tanuló vizsgálatára került sor a tanév kezdetekor egy digitális, gyermekek számára kialakított ritmikai szinkronizációt és spontán motoros tempót mérô teszt, valamint egy ritmusreprodukciós feladatsor segítségével. A tanév végén felmértük a gyerekeket a fonológiai tudatosság, valamint a szóolvasás területein. Az olvasás színvonala és a fonológiai tudatosság is szignifikáns kapcsolatot mutatott a szinkronizációs és a spontán tempó feladat több mutatójával, ugyanakkor a ritmusreprodukciós feladat nem rendelkezett hasonló prediktív erốvel. Bár a minta nagysága messzemenô következtetések levonására nem alkalmas, az eredmények egy irányba mutatnak a külföldi szakirodalomban találhatókkal, és azonkíül, hogy további vizsgálatok szükségességét jelzik, felhívják a figyelmet a korai ritmikai fejlesztés fontosságára.
\end{abstract}

Kulcsszavak: ritmusérzék, szenzomotoros szinkronizáció, fonológiai tudatosság, olvasás 
A ritmussal történô együttmozgás nem csak kulturális univerzálé (Nettl, 2000), de az emberi fajt specifikusan jellemzô prediszpozíció és képesség. Gyakran tudattalanul, automatikusan, akár akaratunk ellenére is szinkronizáljuk mozgásunkat a zene ritmusához (Repp, 2005; Repp és Su, 2013). A zene és a beszélt nyelv észlelése a hangok több tulajdonságának pontos feldolgozásán és ezek precíz, gyakran kategorikus reprezentációin alapul, mint a hangmagasság, a hangerô, a hosszúság vagy a hangszín (Besson és Schön, 2011). A zenei tevékenységek bizonyítottan javítják a beszéd észlelését (Kraus és Chandrasekaran, 2010), ami megmutatkozik például felnôtt zenészek agytörzsi kiváltott potenciálokkal vizsgált beszédhang-feldolgozási folyamataiban (Wong, Skoe, Russo, Dees és Kraus, 2007). A zenét tanuló gyerekeknek magasabb a verbális intelligenciája (Moreno és Bidelman, 2014), valamint jobb szegmentálási teljesítményt mutatnak egy mesterséges nyelv statisztikai jellemzóit felhasználva (François, Chobert, Besson és Schön, 2013).

Számos kutatás eredménye látszik alátámasztani azt a gyakorlatból is ismert megfigyelést (pl. Meixner, 1993), miszerint különösen gyakran járnak együtt a ritmikai és a nyelvi képességek. Ezt a kapcsolatot megfigyelték tipikus (Bonacina, Krizman, WhiteSchwoch és Kraus, 2018; David, Wade-Woolley, Kirby és Smithrim, 2007; Gordon és mtsai, 2015; Politimou és mtsai, 2019) és atipikus nyelvi fejlôdésú, elsôsorban diszlexiával (Colling, Noble és Goswami, 2017; Flaugnacco és mtsai, 2015, 2014; Wolff, 2002; Woodruff Carr, White-Schwoch, Tierney, Strait és Kraus, 2014), illetve specifikus nyelvi zavarral küzdő gyerekek körében egyaránt (Alcock, Passingham, Watkins és VarghaKhadem, 2000; Corriveau és Goswami, 2009; Cumming, Wilson, Leong, Colling és Goswami, 2015; Richards, 2017). Jelen kutatásunkban arra a kérdésre kerestük a választ, hogy 6-7 éves, tipikusan fejlôdô iskolakezdô gyerekek ritmikai feladatokban nyújtott teljesítménye eloorejelzi-e a tanév végén mért eredményeiket a fonológiai tudatosság, illetve a szóolvasás területein. Saját fejlesztésû, digitális teszttel mértük fel a spontán tempó produkciójukat, három különbözó tempójú zenéhez történô mozgásos szinkronizációjukat, valamint elvégeztek egy ritmusreprodukciós feladatsort is. A szinkronizációs feladatban használt zenés ingeranyag a vizsgált korosztály számára játékos és motiváló, ezért alkalmasabbnak tartjuk felmérésükre, mint a széles körben elterjedt metronómhangot.

\section{A SZENZOMOTOROS SZINKRONIZÁCIÓ (SMS) ÉS A SPONTÁN MOTOROS TEMPÓ (SMT)}

A tempó produkció területén kétféle ritmikus viselkedést vizsgálhatunk: az izokrónikus, vagyis saját magához képest egyenletes, és a szinkronizált mozgást, amely valamilyen külsố ingerhez igazodik (Rocha-Thomas, 2018). Az elsốt spontán motoros tempónak (spontaneous motor tempo, SMT), az utóbbit szenzomotoros szinkronizációnak (sensorimotor synchronization, SMS) nevezzük. A spontán tempót mérô feladatok során nincs külsố referencia, a vizsgálati személyt arra kérik, hogy kényelmes, egyenletes tempóban valamilyen egyszerú mozgást végezzen, amely általában ujjhegygyel való kopogást jelent. Ekkor a felvett tempó nagysága, az ütések szórása és a kezdô tempótól való eltávolodás mértéke egyaránt informatív. A szinkronizációs képesség 
mérésére a legelterjedtebb kísérleti paradigma az ún. szenzomotoros szinkronizációs feladat. Ennek során a vizsgálati személynek a periodikus hangingerhez (általában metronómhanghoz) alkalmazkodva kell kopognia. Az eljárásnak számos változata ismert, amelyeket részletesen bemutat Bruno Repp két összefoglalója (Repp, 2005; Repp és Su, 2013). A szinkronizáció sikerességét a referenciától való eltérés mértéke és iránya jellemzi. A szinkronizációt követheti egy ún. folytatásos szakasz (continuation phase) hanginger nélkül, amely során a vizsgálati személynek meg kell tartania a felvett tempót. Ebben az esetben az eltávolodás iránya és mértéke a releváns.

Széles körben megfigyelt jelenség, hogy a szinkronizáció során a referenciától való eltérés jellemzően negatív, vagyis a vizsgálati személyek az ingert megelôzô választ adnak. Ennek a neve átlagos negatív aszinkronitás (negative mean asynchrony, NMA). Valószínúleg ennek következménye, hogy referencia hiányában általános a gyorsulás tendenciája. Az NMA mértéke jellemzôen a korral és a zenei képzettséggel csökken. Bár csekély azon kutatások száma, amelyek a hagyományos metronómhangnál komplexebb ingeranyagot használnak, az eddigi megfigyelések szerint ebben az esetben az NMA csökken, vagy akár teljesen el is tünik (Repp, 2005). Snyder és Krumhansl (2001) kísérletükben arra kérték a résztvevôket, hogy számítógéprôl zongorazenét hallgatva, a darab lüktetésével együtt kopogjanak. Az ütések elemzésekor nem találtak szignifikáns NMA-t. Hasonló eredményre jutott Wohlschläger és Koch (2000), amely szerint ha a mérôzés ritmikai szintjénél sûrúbb beosztású a hanginger, az megszünteti a megelôzéses tendenciát. Az NMA jelenségre már egy évszázada felfigyeltek, mégsem sikerült a mai napig egyértelmúen magyarázni (Repp, 2005; Yang és mtsai, 2020). Patel szerint az anticipált válasz bizonyítja, hogy az ember belsố reprezentációval rendelkezik a tempóról, hiszen ha az egyes ingerekre reagálna, a válasz jellemzôen követné az ingert, mint a legtöbb állatfaj esetében.

\section{A SZINKRONIZÁCIÓ ÉS A SPONTÁN TEMPÓ VÁLTOZÁSA A KORRAL}

A felnôttek a tempók széles skáláján képesek szinkronizációra SMS feladatban. Ennek alsó határa kb. $30 \mathrm{bpm}$ (beat per minute, percenkénti ütés), ennél alacsonyabb tempó esetében komoly nehézséget okoz az alkalmazkodás. A felsố korlátot a mozgásos kivitelezés jelenti, amely ujjal kopogásnál 300 és 400 bpm közé esik (Repp, 2006). A gyerekek ezzel szemben lényegesen szúkebb sávban képesek szinkronizációra, a spontán tempójuk környékén. Idővel az SMT csökken, az SMS pedig egyre több tempóban, a spontán tempótól egyre távolabb is lehetségessé válik, valamint pontosabbá, amit az alacsonyabb aszinkronitás és az ütések kisebb variabilitása mutat. Ez a teljesítménybeli javulás számos szerzó szerint az idegrendszer érését jelzi (Drewing, Aschersleben és Li, 2006; McAuley, Jones, Holub, Johnston és Miller, 2006; Thompson, White-Schwoch, Tierney és Kraus, 2015). Mások ezzel szemben felvetik, hogy az SMT mást tükröz, például antropometriai dimenziókat (pl. kar hossza) (Moelants, 2002; Todd és Lee, 2015), vagy kisgyerekek esetében a gondozó hordozási szokásait (Rocha-Thomas, 2018).

A csecsemôknek már születésükkor rendelkezésére áll a zenével együtt mozgás számos előfeltétele. Elektrofiziológiai módszerekkel egy-két napos újszülötteknél is megfigyelhetô érzékenység bizonyos ritmikai, tempó- és ritmusbeli változásokra (Háden, 
Honing, Török és Winkler, 2015; Winkler, Háden, Ladinig, Sziller és Honing, 2009). Öt hónapos babák meg tudnak különböztetni egymástól egyszerú ritmusokat (Chang és Trehub, 1977), hét hónaposan pedig már hatással van a ritmusészlelésükre (ritmikai csoportosításukra), hogy milyen metrumban mozgatják óket a hallgatás közben (Phillips-Silver és Trainor, 2005). Bár a csecsemốk gyakran produkálnak ritmikus, repetitív, izokrónikus mozgásokat, a spontán tempójuktól nem képesek eltérni annak érdekében, hogy külsố referenciához alkalmazkodjanak, vagyis nem jön létre valódi szinkronizáció (Provasi, Anderson és Barbu-Roth, 2014). Zentner és Eerola (2010) 5-24 hónapos gyerekeknél megfigyelték, hogy a magasabb tempójú zenére már gyorsabb mozgással reagálnak, de nem tudják azt a hang periódusához igazítani. Provasi és Bobin-Bègue $(2003,2008) 18$ hónapostól 4 éves korig vizsgálták gyerekek ritmikai szinkronizációs képességeit. A legkorábbi nagymozgásos alkalmazkodást 3,5 éveseknél figyelték meg. Ők már képesek voltak a spontán tempójuktól eltávolodva, 15-20 százalékkal növelni a frekvenciájukat, de csökkenteni nem. Minden korosztály számára könynyebb volt a gyorsulás, mint a lassulás, az utóbbi magasabb variabilitást eredményezett. Az 1 év körüliek variabilitása általában magasabb volt, mint a 4 éveseké. Az izokrónikus mozgás tehát korábban figyelhetô meg, mint a szinkronizált, az alkalmazkodás képessége az ötödik életévre stabilizálódik, ekkorra jelentkezik a felnôttekre jellemzô anticipációs tendencia (NMA) is (Kirschner és Tomasello, 2009). Ezt követôen 6-8 éves kor körül ugrásszerú javulás figyelhetô meg az SMS teljesítményben, amely ezen idôszak végére megközelíti a felnôttek szintjét. Ezzel egy idôben a spontán tempó is látványosan változik: a 4-6 éveseknél mért 150-200bpm körüli tempó 120 bpm környékére csökken, megközelítve a felnôttekre jellemzô kb. 100 bpm-es értéket (Drake, Jones és Baruch, 2000; McAuley és mtsai, 2006). Gembris (2002) szerint a 7-8 év körüli idôszak a ritmikai képességekre általánosan jellemzôen a fejlődés és a fejleszthetôség kiemelt idôszaka, amely után spontán módon további javulás nem figyelhetô meg a teljesítményben.

Van Noorden és De Bruyn (2009, idézi Repp és Su, 2013) 600 fơs kutatásában 3 és 11 év közötti gyerekek szinkronizációs teljesítményét vizsgálták ismert zenei részletekhez, öt tempóban. A legfiatalabbak nem voltak képesek alkalmazkodni a zenéhez, végig 120 bpm körüli tempóban kopogtak. A sikeres szinkronizáció 5 éves kortól vált általánossá. A szerző́k a „rezonanciaelmélet” (Van Noorden és Moelants, 1999) keretében magyarázták az eredményeket. Szerintük a kisebb gyerekek spontán tempóját tükrözi a 120 bpm-es érték, a szinkronizációs tartományuk pedig ekkor még igen szúk, majd a korral egyre szélesedik, elsôsorban magasabb a tempók felé.

\section{RITMUS ÉS NYELV KAPCSOLATÁT MAGYARÁZÓ ELMÉLETEK}

A zenei tevékenységek számos kognitív területen fejtenek ki jótékony hatást a verbális memória és fluencia, a beszédészlelés, az olvasás, a társas készségek, a finommotorika, a téri és idôi orientáció, a végrehajtó funkciók és az általános intelligencia esetében, összegzi Miendlarzewska és Trost metaanalízise (2014). Moreno (Moreno és Bidelman, 2014; Moreno és Farzan, 2015) elmélete szerint az ún. közeli transzferhatásoknál az észlelés mediál a különbözô területek közt, míg a távoliaknál a végrehajtó funkciók, 
különös tekintettel a gátlásra. Bár a fenti megállapítások a transzferkutatások irodalmából származnak, és csak korlátozottan alkalmazhatók az általunk vizsgált területen, Provasi és munkatársai (2014) is kiemelik a gátló funkció fontosságát a sikeres szinkronizációban. Ozernov-Palchik és Patel (2018) metaanalízisükben a ritmikai képességek és az olvasás kapcsolatát vizsgáló kutatásokat elemezve megállapították, hogy a tempóval kapcsolatos („beat-based”) tesztek a gyerekeknél stabilan együtt járnak az olvasás színvonalával. Ez azonban direkt módon nem magyarázható, mivel a beszélt nyelv ugyan ritmikus, de nem rendelkezik zenei értelemben vett tempóval. A szerzók szerint a beszélt nyelv észlelt regularitásai alapján tett predikciók (prediktív kódolás) segítik a pontos fonológiai reprezentációk létrejöttét, amelyek aztán a fonéma-graféma megfeleltetés elsajátítását könnyítik meg. Ezáltal a hanginger regularitásainak észlelése a két terület kapcsolatáért felelôs háttérváltozó, amely a tempóval kapcsolatos ritmikai feladatokban is megmutatkozik, hiszen az egyenletes tempó egyfajta „kognitív állványozásként" teszi lehetôvé az elôrejelzést.

A nyelvi észlelés során is feltételezhetôen szerepe van a szinkronizációs mechanizmusnak. A hallókéreg egyes sejtcsoportjai képesek a rezgésükkel „követni” az ingerfolyam amplitúdóváltozásait, egyes szerzôk szerint ez teszi lehetôvé a sikeres szegmentációt (Giraud és Poeppel, 2012). Az ezen elképzelésen alapuló elméletek közül Usha Goswami „Temporal Sampling Theory” (TST) kerete szerint a különböző nyelvi szintek szegmentációja más és más frekvenciájú feldolgozást igényel, a hangsúlyos szótagok például kb. $2 \mathrm{~Hz}$-es, míg a fonémák $20 \mathrm{~Hz}$-es frekvenciatartományban kódolódnak. Goswami és munkatársai diszlexiás gyerekek EEG-vizsgálata során a 2 Hz-es (120bpm) frekvenciához történô szinkronizációban valóban szelektív deficitet találtak, amely a szerzô szerint pontatlan fonológiai reprezentációk létrejöttéhez vezet, amelyek a fonológiai tudatosságon keresztül eredményeznek olvasási problémákat (Goswami, 2018). A TST értelmezésében az atipikus nyelvi fejlódésû gyerekek szinkronizációs feladatban mutatkozó alacsonyabb teljesítménye mögött is ez az észlelési deficit állhat, az SMS feladatban mért szinkronizációs pontosság pedig előrejelezheti a gyerekek nyelvi és olvasási szintjét.

Large és Jones (1999) Dynamic Attending Theory (DAT) elmélete a figyelem irányítását helyezi a fókuszba. Szerintük a gazdaságosság érdekében a ritmikus hanginger feldolgozása során a figyelem a hangsúlyos elemekre összpontosul. Az ingerfolyamból „kivont” szabályos struktúra lehetôséget ad az idegrendszernek a predikcióra, így automatizálódhat a feldolgozás. Ez a mechanizmus megmutatkozhat a ritmikai és a nyelvi észlelésben egyaránt, és magyarázhatja a két területen mért teljesítmények együtt járását, ám a területáltalános hatás miatt nem feltétlenül szükséges a fonológiai tudatosság mint mediátor.

McAuley és munkatársai (2006) a spontán tempó jelenségét is a figyelmi viselkedéssel magyarázzák. Részben a DAT-ra alapozva feltételezik, hogy létezik olyan preferált frekvenciája a külsô eseményeknek, amelyhez jobban vagyunk képesek alkalmazkodni a figyelmünkkel. Ez az érték tükrözódik az SMT-ben, és csökken a korral. A szerzók a jelenséget párhuzamba állítják a nyelvelsajátítás folyamatával, amely során a csecsemôk is kezdetben magas, majd egyre alacsonyabb frekvenciatartományú változásokra figyelnek a beszédben. 
A következókben olyan kutatásokat mutatunk be, amelyek a ritmikai és nyelvi területek közti kapcsolat feltárását célozták. Bár a számos kereszt- és hosszmetszeti vizsgálat eredménye alapján egyértelmúen körvonalazódnak összefüggések a ritmusreprodukciós, diszkriminációs, szinkronizációs teljesítmény, illetve a fonológiai tudatosság és az olvasás színvonala között, a bemutatott elméleti keretek különbözôségébool látszik, hogy a ritmikai és nyelvi területek között számos mediáló tényezô állhat, például az auditív észlelés (Goswami, 2018), a figyelmi múködés (Large és Jones, 1999), a végrehajtó funkciók (Moreno és Bidelman, 2014; Moreno és Farzan, 2015) vagy a procedurális emlékezet (Ullman és Pierpont, 2005). Az sem tisztázott egyelôre, hogy a feltételezett háttérváltozók közvetlenül vagy a fonológiai tudatosságon keresztül hatnak az olvasásra. Ezen kérdések megválaszolása a jövóbeli kutatások feladata.

\section{LONGITUDINÁLIS VIZSGÁLATOK}

Mivel a gyerekek ritmusérzékének felmérése korán, már az olvasástanulás megkezdése eloott lehetséges, számos longitudinális kutatás fókuszál a nyelvi és az olvasási teljesítmény előrejelzésének lehetôségére. Az ilyen típusú munkák módszertana rendkívül sokszínú, fôleg a zenei teszteket tekintve. Mivel egyelôre nincs széles körben elterjedt, standardizált tesztcsomag, kutatásonként eltér a használt ingeranyag, a vizsgálati eljárás, a mutatók és a statisztikai feldolgozás is. Ugyanakkor ezek a munkák - bár eredményeik nehezen összehasonlíthatók - ígéretes irányt jelentenek a nyelv és az olvasás problémáinak előrejelzésében.

Moritz és munkatársai (2013) amerikai óvodások ritmusészlelése és a második osztályban mért fonológiai tudatosságuk között találtak kapcsolatot, míg egy másik kutatásban (Lundetræ és Thomson, 2018) norvég gyerekek iskolakezdéskor vizsgált SMS teljesítménye jelezte elôre az év végi olvasási szintjüket. 120 és 90 bpm tempójú metronómhangot használtak, melyek közül az utóbbi, vagyis a lassabb tempójú bizonyult jobb prediktornak. Flaugnacco és munkatársai (2014) 8-11 éves, olasz anyanyelvú gyerekeket vizsgálva kapcsolatot találtak a ritmusreprodukció és az olvasás, valamint a fonológiai tudatosság, illetve a szinkronizáció és egyes nyelvi területek, valamint az olvasás és a hangfelfutási idô észlelése között. Az utóbbi deficitjét találták magyar és angol anyanyelvú diszlexiás gyerekek körében - bár nem azonos mértékben - Surányi és munkatársai (2009).

Bonacina és munkatársai (2018) 5-7 éves, tipikusan fejlődô gyerekek szinkronizációs képességeit vizsgálták, akiknek meglehetôsen alacsony, 54 bpm-es metronómhanghoz kellett tapsolniuk a kezükre erôsített digitális eszközzel. A szinkronizáció pontossága a fonológiai feldolgozás és a szóolvasás mellett korrelált a feldolgozási sebességükkel, a helyesírásukkal, valamint morfológiai és szintaktikai feladatokban mutatott teljesítményükkel.

3-4 éves, tipikusan fejlôdô gyerekeket vizsgáltak számos zenei észlelési és produkciós feladattal Politimou és munkatársai (Politimou, Dalla Bella, Farrugia és Franco, 2019). A ritmusdiszkriminációs feladat, valamint a 120 és 100 bpm tempójú metronómhangos SMS feladat eredményei voltak a fonológiai tudatosság legjobb elörejel- 
zôi. A szerzôk a leütésaszinkronitások szórását használták a szinkronizáció sikerességének mutatójaként, amelyet a két tempójú próba átlagából képeztek.

5 és 8 éves korosztályt mértek fel egy tableten végezhetô zenei feladatsorral Steinbrink és munkatársai (2019). Mindkét korosztályban a ritmusreprodukció és a hangmagasság-észlelés jelezte előre legjobban a fonológiai tudatosságot, amelynek kontrollálása után a ritmusreprodukció az olvasási teljesítménnyel (betúzés) is kapcsolatot mutatott.

Szintén a ritmusreprodukció mutatkozott erôs prediktornak Dellatolas és munkatársai (2009) több mint 1000 fôs, longitudinális kutatásában. 5-6 éves gyerekek 21 ritmust ismételtek el, amelyeket a kísérletvezetó ceruzával ütött az asztallapon. A reprodukciós teljesítményük a második osztályban (7-8 éves korban) mért olvasási teljesítményüket jelezte előre a figyelmi és téri-vizuális teljesítményük parciálása után. Fontos megemlíteni azonban módszertani gyengeségként, hogy a reprodukció sikerességét a vizsgálatvezetô ítélte meg és pontozta.

Maróti és munkatársai (2019) kutatásában három tempóban (90, 120, 150 bpm) végeztek 6-7 éves magyar anyanyelvú gyerekek metronómhang alapján történô SMS feladatot. A lassú tempójú feladat folytatásos szakaszában az ütések variabilitása közepes erôsségú kapcsolatot mutatott a gyerekek fonológiai és figyelmi teljesítményével, valamint a munkamemóriájukkal. Eredményeik érdekessége, hogy nem a szinkronizáció pontossága, hanem a referencia nélküli feladatvégzés során mért konzisztencia volt a meghatározó mutató. Tudomásunk szerint ez idáig az egyetlen publikált kutatás, amelyben magyar anyanyelvú gyerekeket vizsgáltak SMS feladattal, nyelvi tesztekkel összehasonlítva.

A felsorolt kutatások módszertani sokszínúsége a terület fiatalságát tükrözi, ugyanakkor meg is nehezíti a kapott eredmények összehasonlítását. Lényeges különbségeket találunk a használt eszközök területén, a legelterjedtebbek a különbözó MIDI-dobeszközök, amelyek gumifelületét kézzel vagy dobverôvel üti a résztvevô, de egyes vizsgálatokban tablet képernyôjén, számítógép billentyúzetén vagy kézre erôsített eszközzel tapsolva kellett a résztvevôknek kopogni. A választott eszköz jellemzôi és az ütésekhez szükséges mozgás nyilvánvalóan hatással van a kapott eredményekre. A MIDI-eszközök elônye, hogy minimális késéssel (latency), milliszekundum pontosságú mérést tesznek lehetôvé, ezért esett erre a választásunk a saját mérôeszközünk kialakításában is. Az ingeranyag, illetve az elemzés során használt mutatók területén is több megközelítést találunk. Az aszinkronitás mérésénél fontos kérdés, hogy abszolút (pl. $15 \mathrm{~ms}$ ) vagy relatív (pl. 15\%) eltérést mérnek. Az utóbbi elônye, hogy a különbözô tempókban produkált aszinkronitások mértéke összehasonlíthatóvá válik. Szintén lényeges, hogy az eltéréseknek csupán a nagyságát vagy az irányát is figyelembe veszik-e. Meglátásunk szerint mindkét fajta mutató szükséges ahhoz, hogy teljes képet kapjunk a feladatvégzésrôl. Az ingeranyag tekintetében két kérdés is felmerül. Egyrészt a feladatvégzéshez választott tempók sokfélesége, amely alól talán Usha Goswami elméletéhez kapcsolódóan a 2 Hz-es (120 bpm) tempó gyakori használata a kivétel, illetve a hagyományosan alkalmazott metronómhanggal szemben (vagy mellett) a magasabb ökológiai validitást jelentô, de kevésbé kontrollált komplex zenei ingeranyag. 


\section{KUTATÁSOK ZENÉS INGERANYAGGAL}

Kutatásunk szempontjából kiemelt fontosságúak az olyan vizsgálatok, amelyek a zenéhez történố szinkronizációt vizsgálták valamilyen kognitív területtel összefüggésben. Ezek száma igen csekély, módszertanuk különbözô, és egy részük atipikus populációval folyt, így korlátozottan érvényesek az eredményeik a jelen munkára nézve. 5-7 éves gyerekeket vizsgált 85, 110 és 150 tempójú SMS feladattal Einarson és Trainor (2016). Tempóban illesztett próbákat végeztek a gyerekekkel metronómhangot, illetve különbözố stílusú zenei részleteket felhasználva. Ezeket elemezve megállapították, hogy a zene általánosan javította a szinkronizációs teljesítményüket a metronómhoz képest. A 7 éves gyerekek jobban teljesítettek az abszolút szinkronizációs mutató szerint, de a nem abszolút, eltérési irányt is jelzô mutató szerint nem találtak szignifikáns különbséget. Az SMS teljesítmény mutatói és a gyerekek szókincse, illetve munkamemóriája között is találtak kapcsolatot. Cumming és munkatársai (2015) a TST-elmélet alapján 120 bpm tempójú SMS feladatokkal vizsgáltak 9 éves, specifikus nyelvi zavarral (SLI) diagnosztizált gyerekeket. A szinkronizációs feladathoz használt ingeranyag kizárólag zene volt, két, a kutatáshoz komponált instrumentális mú 3/4 és 4/4 metrumban. Ezenkívül több nyelvi és zenei feladattal (ritmus, hangmagasság, illetve tempó diszkrimináció) mérték fel a gyerekeket. A tisztán SLI-diagnózisú csoport és a kontroll között egyedül az SMS feladatban mért teljesítményükben találtak különbséget az IQ kontrollálása után. A szerzôk által közölt nem abszolút aszinkronitási mutatóból általánosan megfigyelhetố adataikon az NMA-jelenség is.

Puyjarinet és munkatársai (2017) 6-12 éves, ADHD-val diagnosztizált gyerekeket vizsgáltak. Három tempóban (80, 100 és 133 bpm) kellett metronómhanghoz mérózniük, valamint két 100 bpm tempójú klasszikus zenei felvételhez (Bach: Badinerie, Rossini: Tell Vilmos nyitány). Ezeken kívül spontán tempó (SMT), illetve tempó- és hosszúságdiszkriminációs feladatokat is végeztek. Az ADHD-s csoport teljesítménye jelentôsen alacsonyabb volt a kontrollhoz képest a hanghosszúságok megítélésében és a tempókövetésben, ami az SMS feladatban mért szinkronizációban is megmutatkozott. A színvonaluk ugyanakkor függött az ingeranyag komplexitásától: a zenéhez történố szinkronizáció lényegesen nehezebb volt számukra a metronómhoz képest. A szerzốk szerint ennek oka, hogy míg a metronóm esetében egyértelmúen adott a ritmikai struktúra, a zenénél ezzel szemben a lüktetést a vizsgálati személynek saját számára, „belsôleg” kell fenntartani a komplex hanginger alapján. Az ADHD-ban érintett gyerekekre általánosan jellemzố gyenge tempókövetést a dinamikus figyelmi múködés deficitjével, vagyis a DAT (Dynamic Attending Theory) keretében magyarázták.

Az önmagában az SMS jelenségeit vizsgáló, korábbi fejezetekben összefoglalt munkák és a fenti kutatások alapján láthatjuk, hogy a zenei ingeranyag hatása a feladatvégzésre nem egyértelmú. Kérdéses az NMA megjelenése, illetve, hogy milyen prediktív erôvel rendelkezik más kognitív területekre nézve. Jelen kutatásunkban, bár a metronómmal való összehasonlításra nem nyílt lehetôség, igyekszünk választ találni ezen kérdésekre. További kérdésként merül fel az intelligencia szerepe, amely nem egyértelmú a ritmikai képességek relációjában. A bemutatott kutatások alapján úgy túnik, 
hogy a szinkronizációs teljesítmény kevéssé függ az intelligenciától, illetve a rövidtávú emlékezettôl (Cumming, Wilson, Leong, Colling és Goswami, 2015; Politimou és mtsai, 2019), ezért jelen vizsgálatunkban eltekintettünk ezek mérésétôl.

\section{CÉLOK, HIPOTÉZISEK}

Kutatásunk célja annak felderítése volt, hogy a gyerekek számára kialakított, zenét használó teszteljárásunk segítségével lehetséges-e a fonológiai tudatosság és az olvasás színvonalának elôrejelzése, ahogy azt alacsony komplexitású ingeranyaggal (többnyire metronómhanggal) számos felsorolt kutatás megtette. Vizsgálatunk a magyar anyanyelvú gyerekekkel végzett hasonló munkák hiányában, illetve a nemzetközi irodalomban tapasztalt módszertani sokszínúség miatt exploratív jellegú. Az ingeranyag megválasztásakor nem nyílt lehetôségünk a metronómhang és a zenei ingeranyag együttes alkalmazására és összehasonlítására, ezért a szóban forgó korosztályra való tekintettel, illetve mert magyar anyanyelvú gyerekekkel korábban nem végeztek hasonló vizsgálatot, az utóbbi mellett döntöttünk. A korábban bemutatott eredmények alapján a következô hipotéziseket fogalmaztuk meg. Feltételeztük, hogy a zenés ingeranyag használata mellett is megjelenik az anticipációs tendencia (NMA) és az ehhez köthetô gyorsulás a feladatok folytatásos szakaszában (H1) (Repp, 2005; Repp és Su, 2013). Arra számítottunk, hogy a kisebb mértékú abszolút aszinkronitás magasabb fonológiai tudatossággal (FT) és olvasási pontszámmal jár együtt (H2) (Bonacina és mtsai; 2018; Dellatolas és mtsai, 2009; Lundetræ és Thomson, 2018; Politimou és mtsai, 2019). Az ütések inkonzisztenciája és a kezdô tempótól való eltávolodás a folytatásos részben egyenes arányosságban áll a FT és az olvasási feladat teljesítményével (H3) (Maróti és mtsai, 2019). Bár az eltávolodás nem konvencionális mutató, korábbi vizsgálatainkban (Kertész, 2018) atipikus nyelvi fejlôdésú gyerekek körében markáns különbséget, lényegesen erôsebb gyorsulásos tendenciát találtunk a kontrollhoz képest, ezért úgy gondoltuk, hogy az inkonzisztenciával hasonlóan negatív kapcsolatot találunk majd a nyelvi és olvasási eredményekkel. Feltételezzük, hogy az alacsonyabb spontán tempó magasabb teljesítménnyel jár együtt az FT és az olvasási feladatban, amennyiben az SMT csökkenése és a konzisztensebb kopogás valóban az idegrendszeri érés indikátora (H4) (Drewing és mtsai, 2006; McAuley és mtsai, 2006; Thompson és mtsai, 2015). Arra számítottunk, hogy a ritmusreprodukciós feladatban elért jobb teljesítmény együtt jár az FT és az olvasási feladat magasabb pontszámaival (H5) (Dellatolas és mtsai, 2009; Flaugnacco és mtsai, 2014; Steinbrink és mtsai, 2019).

\section{MÓDSZER}

A vizsgálat során 2019 októberében összesen 39 iskolakezdô tanuló végezte el a ritmikai tesztbattériánkat, amely egy spontán tempó (SMT) és egy szenzomotoros szinkronizációs (SMS) feladatból, illetve egy ritmusreprodukciós feladatsorból állt (Asztalos Kata által kidolgozott teszt a szerzô engedélyével). A tanév végén, április és május 
hónapokban mértük fel óket a Fonológiai Tudatosság Teszt (Jordanidisz, 2009), illetve a Sipos (2017) által sztenderdizált Meixner-olvasólap segítségével. A résztvevôk a budapesti Németh Imre Általános Iskola tanulói közül kerültek ki, mind önként jelentkeztek, szüleik írásos tájékoztatást kaptak a vizsgálat menetéról, és beleegyezó nyilatkozatot töltöttek ki. A gyerekek átlagos életkora az elsô vizsgálat időpontjában 7,2 év volt $(\mathrm{SD}=0,46)$, a lányok aránya 48,7\%.

\section{Eszközök}

Az SMS és SMT feladatokban a kopogás AKAI LPD-8 MIDI dobpad eszközön történt domináns kézzel, a lejátszás és felvétel Steinberg UR-22 külsô hangkártyával, az ingerbemutatás Audio-Technica ATH-T200 zárt fejhallgatón keresztül. A leütéseket nem követte auditív visszajelzés. A ritmusreprodukciós feladatban a gyerekek tapsolását Olympos WS650S diktafonnal rögzítettük. A hangfeldolgozás Steinberg Cubase 5 szoftverrel történt, az adatelemzés pedig Microsoft Excel 2019, ROPstat és IBM SPSS Statistics 23 programokkal.

\section{Ritmikai feladatok}

1. Spontán tempó feladat (SMT)

A gyerekek ebben a feladatban azt az instrukciót kapták, hogy számukra kényelmes, egyenletes tempóban kopogjanak 30 másodpercen keresztül az eszköz gumilapján. Az elsô 10 érvényes leütésból számoltuk az átlagos tempót (SMT), valamint szórásukból a belsố inkonzisztenciát („SMT inkonzisztencia”). Az utolsó és az elsô 10 leütés különbségébôl számoltuk a kezdố tempótól való elmozdulást („SMT eltávolodás”), amelynek negatív értéke jelentette a gyorsulást, nagyságát pedig a kezdô tempóhoz viszonyítva, százalékos formában adtuk meg.

\section{Ritmikai szinkronizáció (SMS)}

A három szinkronizációs feladatban a résztvevôk komplex instrumentális zenével szinkronban kopogtak negyedritmusos mérôvel 80, 120 és 150 bpm tempóban. Három populáris zenei részletet használtunk: All I have to do is dream (Everly brothers), Michelle (Beatles), Johnny B Goode (Chuck Berry). A zenéket MIDI-formátumból, virtuális hangszerek használatával hoztuk létre úgy, hogy csak három hangszer szólt, nagybôgó, zongora és dob. Az énekszólamot eltávolítottuk, hogy ne legyen hatással a mérôzésre. A zeneszámok kiválasztásával az volt a célunk, hogy a gyerekek ne ismerjék a dalokat, a vizsgálatvezetô erre rá is kérdezett a próbák között. Az adott zene periódusának hosszától függôen a kb. 30 mp-es szinkronizációs szakaszt követôen 20 mp-en keresztül zene nélkül kellett folytatniuk a kopogást („continuation phase”, a továbbiakban „folytatásos szakasz”). Az elsô szakaszban mutatóként használtuk a referenciától való eltérést („aszinkronitás80/120/150”), ahol a negatív érték jelzi az anticipációt. Azért, hogy az ellenkezô előjelû aszinkronitások az átlagoláskor ne „oltsák ki” egymást, hamisan a szinkronitás látszatát keltve, az eltérések abszolút értékébôl is létrehoztunk 
egy mutatót („abszolút aszinkronitás80/120/150”). A folytatásos szakaszban a kezdó tempótól való eltávolodást figyeltük („eltávolodás80/120/150”), ahol a negatív érték ismét gyorsulást jelzett, a pozitív pedig lassulást. A folytatásos szakaszban, mivel a szinkronizációhoz hasonlóan itt nincs lehetôség külsô referenciához mérni, a leütések szórását vizsgáltuk a saját átlaghoz képest („folytatásos inkonzisztencia80/120/150”). Hogy a különbözó tempók mérôszámait össze tudjuk hasonlítani, mindegyiket elosztottuk a hozzá tartozó referenciatempóval. Végül, hogy robusztusabb mutatókkal végezzük a korrelációs elemzéseket, az utóbbi három mérôszám három különbözô tempóban mért értékeinek átlagából összevont mutatókat hoztunk létre (,,abszolút aszinkronitás”, „eltávolodás”, „folytatásos inkonzisztencia”). Mivel az SMT értéke minden vizsgálati személy esetében más, illetve feltételezhetjük, hogy az ettôl való távolság befolyásolja az adott tempóban történô szinkronizációs teljesítményt, a próbák átlaga megfelelố mérôszám a gyerekek teljesítményének jellemzésére (Politimou és mtsai, 2019; Woodruff Carr és mtsai, 2014).

\section{Ritmusreprodukció}

A gyerekek összesen 10, egyre komplexebb, elöre rögzített, tapsolt ritmust hallgattak meg, amelyeket egyenként kellett tapsolva visszaismételniük. A felvételeket 5 felsôfokú zenei végzettséggel rendelkezó szakértô pontozta a teszthez mellékelt javítókulcs alapján. A ritmikai tesztek felvétele összesen kb. 10-15 percet vett igénybe.

\section{Fonológiai tudatosság}

A fonológiai tudatosság felmérésére Jordanidisz (2009) Fonológiai Tudatosság Tesztjének rövidített változatát használtuk, amely a következô feladatokat tartalmazta: rímtalálás, szótagolás, hangszintézis, hasszú hang megnevezés, hangmanipuláció. A szubtesztek eredményein kívül az azok összegéból számolt összpontszámmal is jellemeztük a gyerekek fonológiai tudatosságát, amelyet FT elnevezésû́ változóval jelöltünk.

\section{Olvasás}

A gyerekek olvasási szintjének felmérésére az adott korosztálynak megfelelô Meixner-olvasólap szóolvasás-feladatát használtuk, amelyben a gyerekeknek öt oszlopban felülrôl lefelé haladva kellett összesen ötven, 1-4 szótagos szót idôre felolvasniuk. A Meixner Ildikó által összeállított feladat az adott évfolyam olvasókönyveinek szókincsébôl merít, és a teljes tesztre nézve alapelvként elmondható, hogy az idegen szavak aránya legfeljebb 5\% (Sipos, 2015). Az olvasás fluenciáját az olvasási idôvel, a pontosságot pedig a vétett hibák számával mértük. A Fonológiai Tudatosság Tesztet és a Meixner-olvasólapot független gyógypedagógus vette fel a gyerekekkel. 


\section{Statisztikai elemzés}

A varianciaanalízisek során amennyiben a szfericitás sérült, minden esetben a Geisser-Greenhouse-korrekciót alkalmaztuk, és a korrigált értékeket közöltük, a post hoc elemzéseket Bonferroni-korrekcióval végeztük. A korrelációs elemzések esetében a Pearson-féle együtthatókat közöltük, kivéve ahol ezt külön jeleztük. A nem és a kor hatását parciálással küszöböltük ki. Mivel a nagyszámú korrelációs elemzések esetén felmerül a lehetôség, hogy egyes összefüggések a véletlennek köszönhetôk, FDR- (false discovery rate) korrekciót végeztünk a Benjamini-Hochberg-módszerrel.

\section{EREDMÉNYEK}

\section{A ritmikai feladatok eredményei}

Az SMT feladatban 122,81 bpm-es átlagot mértünk, $(\mathrm{SD}=33,42, \min =55, \max =225)$ és átlagosan -11,55\%-os eltávolodást, vagyis a spontán tempóhoz képest gyorsulásos tendencia volt megfigyelhetô. Az SMS feladatban a három tempójú zenénél változó elôjelú aszinkronitást találtunk. Míg az alacsony és a közepes tempó esetében az átlagos eltérés negatív elôjjelú, vagyis megelôzô, anticipált volt, a gyors tempó esetében a nullához közelítve átlagosan enyhén késett (ld. 1. táblázat). A legnagyobb mértékú negatív aszinkronitást $(-6,37 \%)$ az alacsony tempónál mértük. A feladatok között statisztikailag szignifikáns különbség mutatkozott, $F(1,6,61,6)=12,55, p<, 001$; epszilon = ,81, amelyet a post hoc elemzés az elsố $(80 \mathrm{bpm})$ és második $(120 \mathrm{bpm})$, valamint az elsố és harmadik $(150 \mathrm{bpm})$ tempó közötti különbség esetében erôsített meg, $(k=3, d f$ $=76$ ): $\mathrm{T} 12=4,04, p=, 007, \mathrm{~T} 13=7,06, p=, 001, \mathrm{~T} 23=3,02, p=, 056$. A szinkronizáció pontosságának megítélésére használt abszolút aszinkronitás mutatónál (1. táblázat) a három tempójú feladat közt nem találtunk statisztikailag szignifikáns különbséget, $F(2,76)=2,48, p=, 091$. A tempótól való eltávolodás irányát és nagyságát vizsgálva (1. táblázat) mindhárom tempó esetében gyorsulásos tendenciát találtunk, melynek mértéke a lassú tempó esetében volt a legnagyobb $(-13,35 \%)$, és a gyors zenénél a legkisebb $(-4,86 \%)$. A három feladat közötti különbséget a statisztikai próba igazolta, $F(1,8,66,8)=7,90, p=, 0013$, epszilon $=, 88$, szignifikáns különbség az elsố és a második, valamint az elsố és a harmadik feladat között mutatkozott, $(k=3, \mathrm{df}=76)$ : T12 $=3,97$, $p=, 007, \mathrm{~T} 13=5,43, p=, 006, \mathrm{~T} 23=1,46, p=, 847$. Egyedül a közepes és a gyors tempó között nem bizonyult a különbség statisztikailag szignifikánsnak az átlagok páronkénti összehasonlítása alapján. A folytatásos szakaszban a belsố inkonzisztenciát a leütések saját, átlagos tempóhoz viszonyított szórása jelezte. A három tempóban mért értékek között (1. táblázat) nem tapasztaltunk statisztikailag szignifikáns különbséget az elvégzett varianciaanalízis szerint, $F(2,76)=0,62, p=, 541$. A ritmusreprodukciós feladatban az értékelôk pontozása megfelelô mértékben járt együtt a további elemzések elvégzéséhez az inter-rater reliabilitást jellemzó mutatók szerint: $I C C=, 91, p<.001$, $\operatorname{ICC}(U)=, 91, p<.001$. A feladat során $0-5$ pontot ért egy adott ritmus reprodukciója, így összesen 50 pontot szerezhetett egy résztvevô. Az 1. táblázatban a szerzett pontok százalékos arányát közöljük az elérhetô maximumhoz képest. 
1. táblázat. Az SMS, SMT, ritmusreprodukciós, valamint a fonológiai tudatosság és szóolvasás feladatok mutatói és értékei

\begin{tabular}{lccr}
\hline Változó & $\mathrm{M}(\mathrm{SD})$ & Változó & $\mathrm{M}(\mathrm{SD})$ \\
\hline aszinkronitás $(80)$ & $-6,37(8,36)$ & SMT (spontán tempó) & $122,81(33,42)$ \\
aszinkronitás (120) & $-2,45(7,51)$ & SMT inkonzisztencia & $8,59(5,22)$ \\
aszinkronitás $(150)$ & $0,49(6,54)$ & SMT eltávolodás & $-11,55(18,69)$ \\
absz. aszinkronitás $(80)$ & $13,56(5,96)$ & ritmusreprodukció & $28,35(7,69)$ \\
absz. aszinkronitás $(120)$ & $12,65(6,31)$ & szótagolás & $73,33(23,77)$ \\
absz. aszinkronitás (150) & $15.35(7,77)$ & rímtalálás & $42,31(21,94)$ \\
eltávolodás (80) & $-13,35(14,62)$ & hangszintézis & $59,74(21,09)$ \\
eltávolodás (120) & $-7,14(10,86)$ & hosszú hang megnevezés & $52,43(16,29)$ \\
eltávolodás (150) & $-4,86(9,58)$ & hangmanipuláció & $56,49(25,47)$ \\
folyt. inkonziszencia (80) & $12,94(7,33)$ & FT összpontszám & $56,86(14,73)$ \\
folyt. inkonziszencia $(120)$ & $11,78(5,90)$ & szóolvasás hiba & $4,39(3,80)$ \\
folyt. inkonziszencia $(150)$ & $13,13(6,49)$ & szóolvasás fluencia & $95,08(50,42)$ \\
absz. aszinkronitás & $13,85(5,04)$ & & \\
eltávolodás & $-8,45(8,81)$ & & \\
folyt. inkonzisztencia & $12,61(4,59)$ & & \\
\hline
\end{tabular}

\section{A ritmikai és a nyelvi, olvasási feladatok kapcsolata}

A Fonológiai Tudatosság Teszt szubtesztjeinek értékeit százalékos formában tartalmazza az 1. táblázat, csakúgy, mint az összesített „FT összpontszám” mutató. A szóolvasás feladatnál a hibázások abszolút száma, valamint a feladattal töltött idó (mp) szerepel. A fonológiai tudatosság, illetve a szóolvasás-feladat és a ritmikai feladatok mutatóinak kapcsolatát Pearson, illetve ahol a változók normalitása sérült, Spearman-féle korrelációk segítségével jellemeztük (2. táblázat).

2. táblázat. A fonológiai tudatosság és a szóolvasás pontszámainak korrelációi a ritmikai szinkronizációs feladatok mutatóival

\begin{tabular}{|c|c|c|c|c|c|c|}
\hline Változók & $\begin{array}{c}\text { Abszolút } \\
\text { aszinkro- } \\
\text { nitás } \\
\end{array}$ & Eltávolodás & $\begin{array}{c}\text { Folytatásos } \\
\text { inkonzisz- } \\
\text { tencia } \\
\end{array}$ & SMT & $\begin{array}{c}\text { SMT } \\
\text { inkonzisz- } \\
\text { tencia }\end{array}$ & $\begin{array}{c}\text { Ritmus- } \\
\text { rep. }\end{array}$ \\
\hline Szótagolás ${ }^{\mathrm{a}}$ & ,30+ &, $47 * *$ &,$- 50 * *$ &,$- 29+$ &,- 06 &, 17 \\
\hline Rímtalálás & ,13 & ,29+ &,- 15 &, 04 &,$- 33 *$ &,- 10 \\
\hline Hangszintézis &, 04 &, 17 &,- 14 &, 06 & 01 & ,26 \\
\hline $\begin{array}{l}\text { Hosszú hang } \\
\text { megnevezés }\end{array}$ & $-\mathrm{A} 3$ &, $35^{*}$ &,$- 42 * *$ &,$- 38 *$ &,- 18 & ,24 \\
\hline Hangmanipuláció & ,20 &, $35^{*}$ &,- 19 &,$- 30+$ &,- 19 & ,06 \\
\hline FT összpontszám & ,12 &, $\mathbf{5 3} * *$ &,$- 40 *$ &,$- 29+$ &,- 23 & ,18 \\
\hline Szóolvasás hiba &,- 26 &,$- 41 *$ & ,18 &, $54 * *$ & $-/ 05$ &,- 00 \\
\hline Szóolvasás fluencia &,$- 40 *$ &,$- 33 *$ & 21 &, $45^{* *}$ & $-/ 05$ & 13 \\
\hline
\end{tabular}

$* \mathrm{p}<, 05 ; * * \mathrm{p}<, 01 ; * * * \mathrm{p}<, 001 .^{\mathrm{a}}=$ A normalitás sérülése miatt Spearman-féle korrelációt alkalmaztunk. 


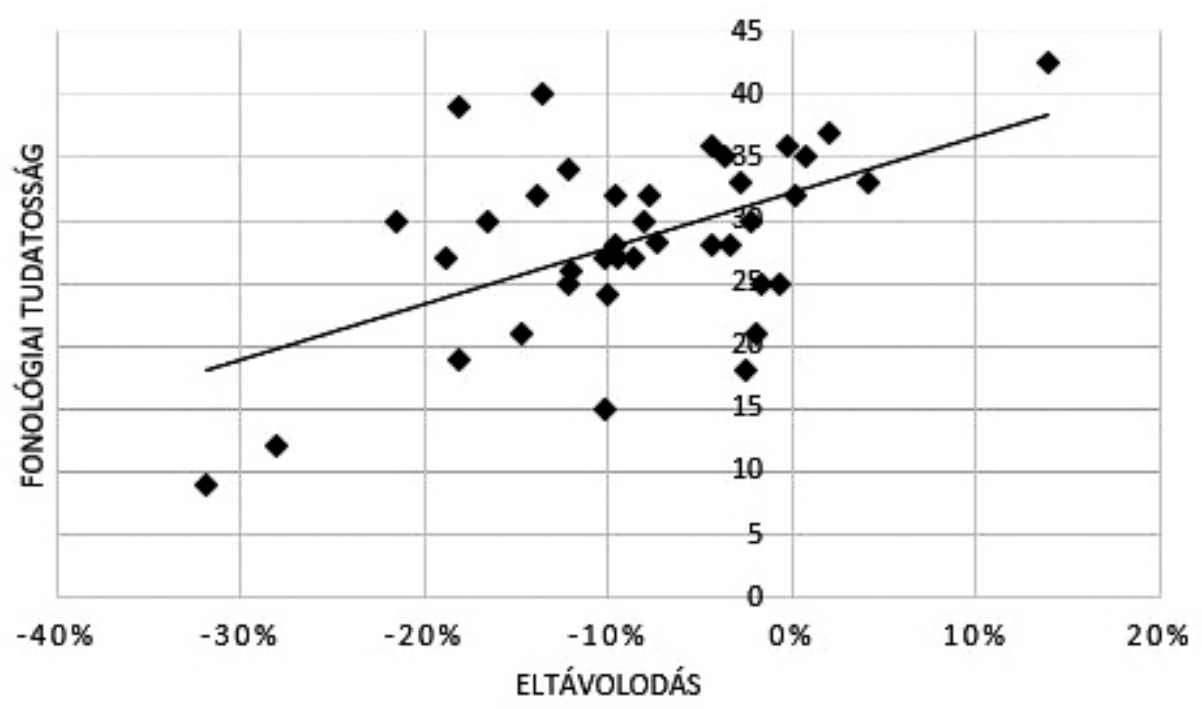

1. ábra. A fonológiai tudatosság és a folytatásos szakaszban mért eltávolodás kapcsolata $(\mathrm{r}=, 53, \mathrm{p}=, 001)$

A fonológiai tudatosság összpontszáma az eltávolodás $(r=, 53, p=, 001)$ (1. ábra) és a folytatásos inkonzisztencia $(r=-, 40, p=, 015)$ mutatókkal állt szignifikáns kapcsolatban, valamint tendenciaszinten együtt járt a spontán tempó nagyságával $(r=-, 29$, $p=, 078)$. Az FT szubtesztek közül a szótagolás és a hosszú hang megnevezés is több, míg a „rímtalálás” és a hangmanipuláció egy-egy SMS vagy SMT mutatóval állt közepes erôsségú kapcsolatban.

A szóolvasási feladat fluencia mutatója az abszolút aszinkronitás $(r=-, 40, p=, 016)$, az eltávolodás $(r=-, 33, p=, 043)$ és az SMT $(r=, 45, p=, 005)$ változókkal járt együtt közepes erôsséggel. A szóolvasási hibák száma szintén az eltávolodással $(r=-, 41$, $p=, 013)$, valamint a spontán tempó nagyságával $(r=, 54, p=, 001)$ állt kapcsolatban. A ritmusreprodukció sem a fonológiai tudatosság feladat szubtesztjeivel, sem a szóolvasás mutatóival nem mutatott szignifikáns együtt járást.

\section{A fonológiai tudatosság és az olvasás kapcsolata}

Mivel a fonológiai tudatosság alacsony szintje nem feltétlenül vezet gyengébb olvasáshoz (Csépe, 2014; Török és Hódi, 2015), az elemzésben kitértünk a két terület közti kapcsolatra is (3. táblázat). Közepes erôsségú, szignifikáns korrelációt találtunk az olvasás fluenciája és a hosszú hang megnevezés $(r=-, 38, p=, 022)$, illetve a szótagolás között $\left(r_{s}=-, 47, p=, 004\right)$, valamint tendenciaszintú együtt járást a fonológiai tudatosság összpontszámával $(r=-, 29, p=, 083)$. A szóolvasási hibák száma együtt járt a FT összpontszámmal $(r=-, 49, p=, 002)$, a szótagolással $(r=-, 62, p<, 001)$, a hoszszú hang megnevezéssel $(r=-, 50, p=, 002)$, valamint a hangmanipulációval $(r=-, 52$, $p=, 001)$. 


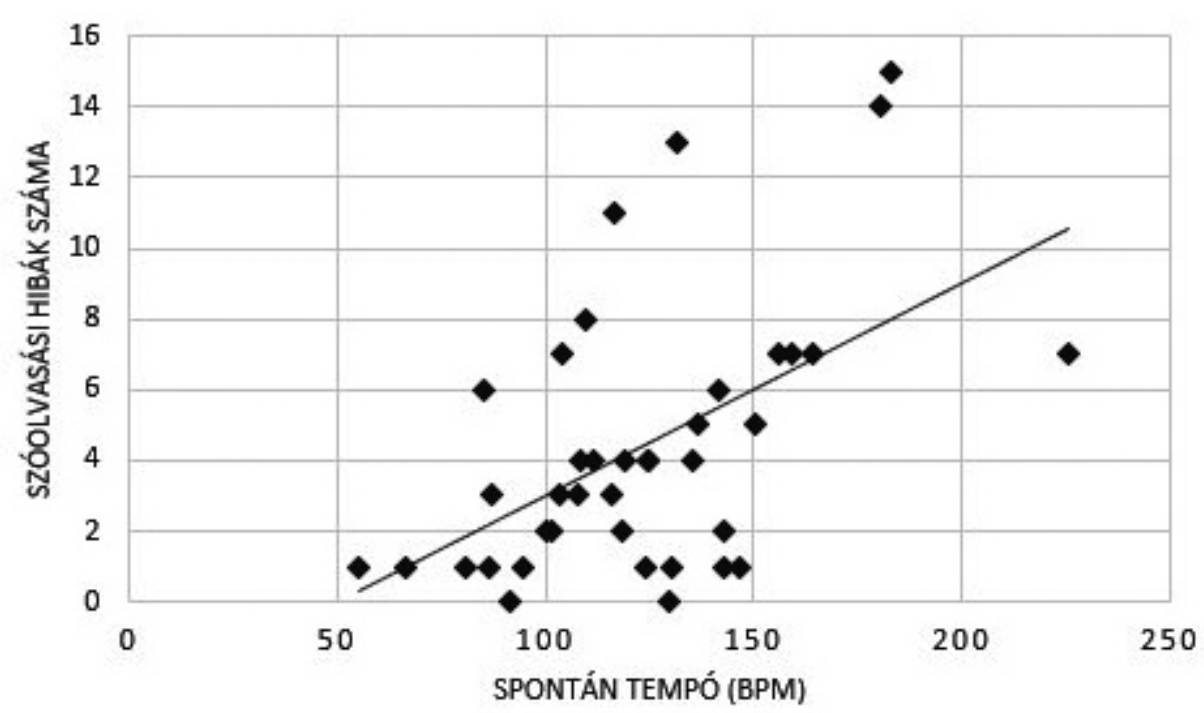

2. ábra. A spontán tempó (SMT) és a szóolvasási hibák kapcsolata $(\mathrm{r}=, 54, \mathrm{p}=, 001)$

3. táblázat. A fonológiai tudatosság szubtesztjeinek és a szóolvasás fluenciájának, valamint a szóolvasási hibák számának Pearson-féle korrelációi

\begin{tabular}{lcccccc}
\hline Változó & FT ossz. & Rímtalálás & Szótagolás $^{\mathrm{a}}$ & Hangszint. & H. h. megn. & Hangman. \\
\hline Szóolvasás fluenda &,$- 29+$ &,- 16 &,$- 47 * *$ &, 12 &,$- 38^{*}$ &,- 27 \\
Szóolvasás hibák &,$- 49 * *$ &,- 08 &,$- 62 * *$ &, 04 &,$- 50 * *$ &,$- 52 * *$ \\
\hline
\end{tabular}

$* \mathrm{p}<, 05 ; * * \mathrm{p}<, 01, * * * \mathrm{p}<, 001$

a = A normalitás sérülése miatt Spearman-féle korrelációt alkalmaztunk.

\section{DISZKUSSZIÓ}

Kutatásunkban arra kerestük a választ, hogy a vizsgált korosztály számára kialakított instrumentális zenei ingeranyagot használó tesztünkkel előrejelezhetô-e a fonológiai tudatosság és az olvasás szintje. Az elemzések alapján megállapítható, hogy a tanév elején felvett ritmikai tesztek közül a ritmikai szinkronizációs (SMS), valamint a spontán tempó (SMT) feladat több mutatója is elôrejelezte az év végén mért fonológiai tudatosság és az olvasás szintjét. Az SMT feladatban a korábbi eredményekhez hasonló (Drake és mtsai, 2000; McAuley és mtsai, 2006), alacsonyabb, 120 bpm körüli átlagos értéket találtunk, bár az említett szerzók mintáiban ehhez hasonló átlagos SMT inkább a 8 év feletti gyerekekre volt jellemzô. A feladatban általánosan megfigyelhetô volt a negatív aszinkronitás, vagyis anticipált válasz (NMA) jelenségéhez köthetô gyorsulásos tendencia (H1). A jelen vizsgálat eredményei, melyek szerint az alacsony SMT járt együtt a fluensebb és pontosabb olvasással, valamint a Fonológiai Tudatosság Teszt „hosszú hang megnevezés”, illetve tendenciaszinten a „szótagolás” szubtesztjével, nem mond ellent azon szerzôk álláspontjának, akik szerint az SMT csökkenése az idegrend- 
szer érésének indikátora lehet (H4). Összevetve az SMT átlagos értékét a szinkronizációs feladatokkal, az eredményeink megerôsítik a többek által leírt (Drake és mtsai, 2000; McAuley és mtsai, 2006; Van Noorden és De Bruyn, 2009, idézi Repp és Su, 2013) jelenséget, mely szerint a spontán tempó környékén sikeresebb a szinkronizáció. Valóban a 120-as tempójú zenénél volt a legalacsonyabb az abszolút aszinkronitás. A másik (nem abszolút) aszinkronitási mutatónál a 80-as és 120-as tempóban negatív értékeket találtunk, vagyis megmutatkozott a szakirodalomból ismert negatív átlagos aszinkronitás (NMA), annak ellenére, hogy egyes szerzók szerint (Repp, 2005; Snyder és Krumhansl, 2001; Wohlschläger és Koch, 2000) a zenés ingeranyag esetében ennek eltûnésére lehetett volna számítani (H1). A 150 bpm-es zenénél ez az érték nullához közeli, enyhén pozitív volt, de összevetve az abszolút aszinkronitási mutatóval, amely ebben a tempóban volt a legmagasabb, arra következtethetünk, hogy a nulla körüli érték nem pontosságot, hanem a hibázások jellegének megváltozását takarja. A gyerekek egyaránt kopogtak a referencia előtt és után, de összességében pontatlanabbak voltak. Bár korábbi kutatások szerint (Drake és mtsai, 2000; McAuley és mtsai, 2006) a 150-es tempónál magasabbat is képesek produkálni ebben a korosztályban, ha az a feladat, hogy a lehetô leggyorsabb mozgást végezzék, feltételezhetôen az alkalmazkodás nagyobb kihívást jelent az adott sebességnél. Az NMA megfigyelt jelenléte (H1) megerôsíteni látszik számunkra a zenés ingeranyag alkalmazhatóságát, bár annak a hagyományos, metronómhanggal való összehasonlítására a jelen vizsgálat során nem volt lehetôség. Az SMS mutatók közül a - szintén az NMA jelenséghez köthetô - eltávolodás bizonyult a legjobb elốrejelzônek (H3). Közepes erôsségű együtt járást találtunk a FT összpontszámmal, a szóolvasás fluenciájával és a hibák számával egyaránt. Ahogy korábban írtuk, az eltávolodás negatív értéke jelentette a gyorsulást, és az ennek a tendenciának való ellenállást tekintjük a jobb teljesítménynek. Az együtt járás nemcsak a nulla értékig, hanem azon túl is megfigyelhetô volt, vagyis azok a gyerekek teljesítettek a legjobban, akik a zene megszúnése után olyannyira ellenálltak a gyorsulásos késztetésnek, hogy az eredeti tempó alá csökkentettek (H3). Az eltávolodás mutató kiemelkedô prediktív értékének magyarázatára valószínûnek tûnik számunkra a gátló funkció mint háttérváltozó szerepe (Moreno és Bidelman, 2014; Moreno és Farzan, 2015; Provasi és mtsai, 2014). A két inkonzisztencia mutató esetében is szignifikáns kapcsolatot találtunk az SMS feladatban, Maróti és munkatársai (2019) eredményeihez hasonlóan, a folytatásos szakaszra számolt relatív szórás a FT összpontszámmal és két szubteszttel (szótagolás és hosszú hang megnevezés) állt közepes erôsségú kapcsolatban (H3), az SMT feladat hasonló mutatója pedig a rímtalálással (H4). Az abszolút aszinkronitás mutató esetében ellentmondásos eredményeket kaptunk. Tendenciaszintû együtt járást mutatott a szótagolás szubteszttel, ugyanakkor szignifikánsan, de negatívan korrelált a szóolvasási idôvel, vagyis a jobban szinkronizálók kevésbé fluensen olvastak (H2). Távolabbról tekintve az SMS és SMT feladatokra, a szabályos, izokrón mozgást mérô mutatók jelezték elôre az év végi fonológiai tudatosságot és a szóolvasás szintjét, a szinkronizációs teljesítmény azonban nem. Két magyarázat is kínálkozik számunkra. Puyjarinet és munkatársai (2017) szerint a külsô referenciával, illetve az önállóan végzett kopogás között minôségi különbség van, mivel az utóbbinál szükséges a tempó belsố reprezentációjának fenntartása, így a feladatvégzés a munkamemóriát is igénybe veszi. A késôbbi vizsgálatok során ezért indokolt- 
nak tartjuk a gyerekek munkamemóriájának felmérését is. A másik elképzelés, hogy a vizsgálatban használt ingeranyag komplexitása jelentett túl nagy kihívást számukra. Ennek tisztázására a késóbbi vizsgálatok során az ingeranyag hagyományos metronómhanggal való kiegészítését is tervezzük, ami jelen vizsgálatunk kereteit meghaladta. Meglepó módon a ritmusreprodukciós feladat semmilyen kapcsolatot nem mutatott a fonológiai tudatossággal és az olvasási, nyelvi teljesítménnyel (H5) annak ellenére, hogy a szakirodalomban számos példa ismert ennek ellenkezójére. Egy elképzelhetô magyarázat, hogy a reprodukció magában foglalja a ritmusképletek ismeretét mint deklaratív tudást. Azok a gyerekek, akik már ismerik a Kodály-módszerben használt szótagokat („tá”, „ti-ti”), az észlelésben és a reprodukcióban is jobban teljesíthetnek, ezért nem csupán képességet, hanem tudást is mérünk ezzel a feladattal. A fonológiai tudatosság egyes szubtesztjei és a szóolvasás fluenciája, valamint az olvasási hibák száma között közepes erôsségú kapcsolatot találtunk (3. táblázat).

Bár a fonológiai tudatosság általánosan jó előrejelzôje az olvasás színvonalának, több kutatás is igazolja, hogy az FT területén fellépó deficit nem feltétlenül vezet gyenge olvasáshoz, például a szocioökonómiai státusz (SES) egyfajta védőfaktorként modulálja a kettô kapcsolatát (Csépe, 2014; Török és Hódi, 2015). A SES és egyéb - az olvasás szempontjából feltételezhetôen lényeges magyarázóerôvel bíró - változók, mint például a gyors megnevezési (RAN) teljesítmény mérése nem volt része a vizsgálatunknak, de késôbbi kutatások során megfontolandó ezek beépítése is a tesztbattériába, csakúgy, mint az IQ, illetve a rövidtávú memória kontrollálása, amelyektôl vizsgálatunkban a szakirodalomból megismert eredmények miatt eltekintettünk. Jelen kutatásunkban nem nyílt lehetôség a ritmikai és nyelvi, olvasási tesztek két idôpontban, a tanév elején és végén való felvételére. Bár az e területen végzett hasonló vizsgálatoknak egy éves intervallumon belül jellemzően nem szokott része lenni, a késôbbi kutatások során az ismételt mérés betekintést nyújthatna nemcsak a két terület fejlôdésébe, hanem a köztük lévô kapcsolat esetleges változásába is. Ennek megismerése lényeges, hiszen maga az olvasástanulás is átformálja az idegrendszert, illetve a fonológiai tudatosság fonémamúveleti szintje is e folyamat során jelenik meg (Csépe, 2006).

Késôbbi kutatások során szintén lényeges kérdés az ingeranyag komplexitásának szerepe. Az azonos tempójú metronómhangos feladatok kontrollként való alkalmazása választ adhat a szakirodalomban egyelôre ellentmondásos kérdésre, miszerint a komplexebb és magasabb ökológiai validitású zenés ingeranyag segíti, vagy éppen megnehezíti a gyerekek számára a szinkronizációt, illetve hogy melyik rendelkezik nagyobb prediktív erôvel a nyelvi és olvasási területeken.

\section{KONKLÚZIÓ}

Jelen kutatásunkban az elsô osztályosokkal a tanév elején felvett SMS és SMT feladatok több mutatója is jó elörejelzônek bizonyult az év végén mért fonológiai tudatosság és olvasási színvonal tekintetében. A digitális, zenés ingeranyagot használó teszteljárásunk alkalmasnak bizonyult a 6-7 éves korosztály vizsgálatára, és az elterjedt, metronómhangot használó eljárásokkal szemben játékos, motiváló feladatvégzést tett lehetôvé. További vizsgálatok szükségesek annak felderítésére, hogy a ritmus, a nyelv és 
az olvasás területei között milyen háttérváltozók mediálnak. Az aktuális eredmények alapján úgy gondoljuk, jogosan merül fel a végrehajtó funkciók, elsôsorban a gátlás szerepe.

\section{KÖSZÖNETNYILVÁNÍTÁS}

Szeretnénk ezúton is megköszönni az együttmúködést és a segítséget a Németh Imre Általános Iskola pedagógusainak, Tiborcz Mártának, Danyiné Lovas Tímeának, Köröminé Vágó Ágnesnek, dr. Szilágyi Jánosnénak, Gajdács Ibolyának, Kórádi Gyuláné Ágnesnek, valamint Takács Szabolcsnak, Lukács Borbálának, Antal Józsefnek, Kuti Mariannak és Sólyom-Nagy Fanninak.

A tanulmány az Emberi Erôforrások Minisztériuma ÚNKP-18-2 kódszámú Új Nemzeti Kiválóság Programja (Kertész Csaba), valamint a Bolyai János Kutatási Ösztöndíj (Honbolygó Ferenc) támogatásával készült.

\section{IRODALOM}

Alcock, K. J., Passingham, R. E., Watkins, K., \& Vargha-Khadem, F. (2000). Pitch and timing abilities in inherited speech and language impairment. Brain and Language, 75(1), 34-46. https://doi.org/10.1006/brln.2000.2323

Besson, M., \& Schön, D. (2011). What remains of modularity? In Rebuschat, P., Rohrmeier, M., Hawkins, J., Crosseds, I. (Eds), Language and Music as Cognitive Systems (pp. 283-291). Oxford, UK: Oxford University Press.

Bonacina, S., Krizman, J., White-Schwoch, T., \& Kraus, N. (2018). Clapping in time parallels literacy and calls upon overlapping neural mechanisms in early readers. Annals of the New York Academy of Sciences, 1423(1), 338-348. https://doi.org/10.1111/nyas.13704

Chang, H., \& Trehub, S. E. (2017). Infants' Perception of Temporal Grouping in Auditory Patterns. Child Development Stable, 48(4), 1666-1670. http://www.jstor.org/stable/1128532 R

Colling, L. J., Noble, H. L., \& Goswami, U. (2017). Neural Entrainment and Sensorimotor Synchronization to the Beat in Children with Developmental Dyslexia: An EEG Study. Frontiers in Neuroscience, 11, 360. https://doi.org/10.3389/fnins.2017.00360

Corriveau, K. H., \& Goswami, U. (2009). Rhythmic motor entrainment in children with speech and language impairments: Tapping to the beat. Cortex, 45(1), 119-130. https://doi. org/10.1016/j.cortex.2007.09.008

Cumming, R., Wilson, A., Leong, V., Colling, L. J., \& Goswami, U. (2015). Awareness of Rhythm Patterns in Speech and Music in Children with Specific Language Impairments. Frontiers in Human Neuroscience, 9, 672. https://doi.org/10.3389/fnhum.2015.00672

Csépe, V. (2006). Az olvasó agy. Akadémiai.

Csépe, V. (2014). Az olvasás rendszere, fejlôdése és modelljei. In Pléh, Cs., Lukács, Á. (szerk.), Pszicholingvisztika 1-2. Magyar pszicholingvisztikai kézikönyv (pp. 339-370). Budapest, Akadémiai Kiadó.

David, D., Wade-Woolley, L., Kirby, J. R., \& Smithrim, K. (2007). Rhythm and reading development in school-age children: A longitudinal study. Journal of Research in Reading, 30(2), 169-183. https://doi.org/10.1111/j.1467-9817.2006.00323.x 
Dellatolas, G., Watier, L., Le Normand, M. T., Lubart, T., \& Chevrie-Muller, C. (2009). Rhythm reproduction in kindergarten, reading performance at second grade, and developmental dyslexia theories. Archives of Clinical Neuropsychology, 24(6), 555-563. https://doi. org/10.1093/arclin/acp044

Drake, C., Jones, M. R., \& Baruch, C. (2000). The development of rhythmic attending in auditory sequences: Attunement, referent period, focal attending. Cognition, 77. https://doi. org/10.1016/S0010-0277(00)00106-2

Drewing, K., Aschersleben, G., \& Li, S.-C. (2006). Sensorimotor synchronization across the life span. International Journal of Behavioral Development, 30(3), 280-287. https://doi. org/10.1177/0165025406066764

Einarson, K. M., \& Trainor, L. J. (2016). Hearing the beat: Young children's perceptual sensitivity to beat alignment varies according to metric structure. Music Perception: An Interdisciplinary Journal, 34(1), 56-70.

Flaugnacco, E., Lopez, L., Terribili, C., Montico, M., Zoia, S., \& Schön, D. (2015). Music training increases phonological awareness and reading skills in developmental dyslexia: A randomized control trial. PLoS ONE, 10(9), 1-17. https://doi.org/10.1371/journal.pone.0138715

Flaugnacco, E., Lopez, L., Terribili, C., Zoia, S., Buda, S., Tilli, S., et al. (2014). Rhythm perception and production predict reading abilities in developmental dyslexia. Frontiers in Human Neuroscience, 8, 392. https://doi.org/10.3389/fnhum.2014.00392

François, C., Chobert, J., Besson, M., \& Schön, D. (2013). Music training for the development of speech segmentation. Cerebral Cortex, 23(9), 2038-2043. https://doi.org/10.1093/cercor/bhs 180

Gembris, H. (2002). Grundlagen musikalischer Entwicklung unter dem spezifischen Aspekt der Kommunikation. www.groups.uni-paderborn.de/ibfm

Giraud, A. L., \& Poeppel, D. (2012). Cortical oscillations and speech processing: Emerging computational principles and operations. Nature Neuroscience, 15(4), 511-517. https://doi. org/10.1038/nn.3063

Gordon, R. L., Shivers, C. M., Wieland, E. A., Kotz, S. A., Yoder, P. J., \& Devin Mcauley, J. (2015). Musical rhythm discrimination explains individual differences in grammar skills in children. Developmental Science, 18(4), 635-644. https://doi.org/10.1111/desc.12230

Goswami, U. (2018). A Neural Basis for Phonological Awareness? An Oscillatory Temporal-Sampling Perspective. Current Directions in Psychological Science, 27(1), 56-63. https://doi. org/10.1177/0963721417727520

Háden, G. P., Honing, H., Török, M., \& Winkler, I. (2015). Detecting the temporal structure of sound sequences in newborn infants. International Journal of Psychophysiology, 96(1), 23-28. https://doi.org/10.1016/J.IJPSYCHO.2015.02.024

Jordanidisz, Á. (2009). A fonológiai tudatosság fejlôdése az olvasástanulás idôszakában. Anyanyelv-Pedagógia, 2(4).

Kertész, Cs. (2018) Ritmus és nyelv - atipikus nyelvi fejlódésú gyerekek zenei tempótartásának vizsgálata számítógépes mérôeszközzel. Pécs, PTE MK Zenemúvészeti Intézet.

Kirschner, S., \& Tomasello, M. (2009). Joint drumming: social context facilitates synchronization in preschool children. Journal of Experimental Child Psychology, 102(3), 299-314.

Kraus, N., \& Chandrasekaran, B. (2010). Music training for the development of auditory skills. Nature Reviews Neuroscience, 11(8), 599-605. https://doi.org/10.1038/nrn2882

Large, E. W., \& Jones, M. R. (1999). The dynamics of attending: How people track time-varying events. Psychological Review, 106(1), 119.

Lundetræ, K., \& Thomson, J. M. (2018). Rhythm production at school entry as a predictor of poor reading and spelling at the end of first grade. Reading and Writing, 31(1), 215-237. https://doi.org/10.1007/s11145-017-9782-9 
Maróti, E., Barabás, E., Deszpot, G., Farnadi, T., Norbert Nemes, L., Szirányi, B., \& Honbolygó, F. (2019). Does moving to the music make you smarter? The relation of sensorimotor entrainment to cognitive, linguistic, musical, and social skills. Psychology of Music, 47(5), 663-679. https://doi.org/10.1177/0305735618778765

McAuley, J. D., Jones, M. R., Holub, S., Johnston, H. M., \& Miller, N. S. (2006). The time of our lives: Life span development of timing and event tracking. Journal of Experimental Psychology: General, 135(3), 348-367. https://doi.org/10.1037/0096-3445.135.3.348

Meixner, I. (1993). A dyslexia prevenció, reedukáció módszere. Budapest: Bárczi Gusztáv Gyógypedagógiai Tanárképzô Főiskola.

Miendlarzewska, E. A., \& Trost, W. J. (2014). How musical training affects cognitive development: Rhythm, reward and other modulating variables. Frontiers in Neuroscience, 7(8 Jan), 1-18. https://doi.org/10.3389/fnins.2013.00279

Moelants, D. (2002). Preferred tempo reconsidered. Proceedings of the 7th International Conference on Music Perception and Cognition, 2002, 1-4. Sydney.

Moreno, S., \& Bidelman, G. M. (2014). Examining neural plasticity and cognitive benefit through the unique lens of musical training. Hearing Research, 308, 84-97. https://doi. org/10.1016/j.heares.2013.09.012

Moreno, S., \& Farzan, F. (2015). Music training and inhibitory control: A multidimensional model. Annals of the New York Academy of Sciences, 1337(1), 147-152. https://doi.org/10.1111/ nyas. 12674

Moritz, C., Yampolsky, S., Papadelis, G., Thomson, J., \& Wolf, M. (2013). Links between early rhythm skills, musical training, and phonological awareness. Reading and Writing, 26(5), 739-769. https://doi.org/10.1007/s11145-012-9389-0

Nettl, B. (2000). An ethnomusicologist contemplates universals in musical sound and musical culture. The Origins of Music, 463-472.

Ozernov-Palchik, O., \& Patel, A. D. (2018). Musical rhythm and reading development: Does beat processing matter? Annals of the New York Academy of Sciences, 1423(1), 166-175. https:/ / doi.org/10.1111/nyas.13853

Phillips-Silver, J., \& Trainor, L. J. (2005). Psychology: Feeling the beat: Movement influences infant rhythm perception. Science, 308(5727), 1430. https://doi.org/10.1126/science.1110922

Politimou, N., Dalla Bella, S., Farrugia, N., \& Franco, F. (2019). Born to speak and sing: Musical predictors of language development in pre-schoolers. Frontiers in Psychology, 10(Apr), 1-18. https://doi.org/10.3389/fpsyg.2019.00948

Provasi, Joëlle, Anderson, D. I., \& Barbu-Roth, M. (2014). Rhythm perception, production, and synchronization during the perinatal period. Frontiers in Psychology, 5(Sep), 1-16. https:// doi.org/10.3389/fpsyg.2014.01048

Provasi, Joëlle, \& Bobin-Bègue, A. (2003). Spontaneous motor tempo and rhythmical synchronisation in 21/2- and 4-year-old children. International Journal of Behavioral Development, 27(3), 220-231. https://doi.org/10.1080/01650250244000290

Provasi, Joëlle, \& Bobin-Bègue, A. (2008). Régulation rythmique avant 4 ans: effet d'un tempo auditif sur le tempo moteur. L’Année Psychologique, 108(4), 631-658.

Puyjarinet, F., Bégel, V., Lopez, R., Dellacherie, D., \& Dalla Bella, S. (2017). Children and adults with Attention-Deficit/Hyperactivity Disorder cannot move to the beat. Scientific Reports, 7(1), 1-11. https://doi.org/10.1038/s41598-017-11295-w

Repp, B. H. (2005). Sensorimotor synchronization: A review of the tapping literature. Psychonomic Bulletin \& Review, 12(6), 969-992. https://doi.org/10.3758/BF03206433

Repp, B. H. (2006). Rate Limits of Sensorimotor Synchronization. Advances in Cognitive Psychology, 2(2), 163-181. https://doi.org/10.2478/v10053-008-0053-9 
Repp, B. H., \& Su, Y.-H. (2013). Sensorimotor synchronization: A review of recent research (2006-2012). Psychonomic Bulletin \& Review, 20(3), 403-452. https://doi.org/10.3758/ s13423-012-0371-2

Richards, S. M. (2017). Rhythmic Sensitivity and Developmental Language Disorder in Children. University of Cambridge.

Rocha-Thomas, S.-E. (2018). Do we dance because we walk? The impact of regular vestibular experience on the early development of beat production and perception. Birkbeck: University of London.

Sipos, Z. (2015) . A 3. évfolyamosok olvasásának vizsgálatára kidolgozott Meixner-olvasólap sztenderdizálásának elsố eredményei. https:/ / docplayer.hu/105487901-A-3-evfolyamosok-olvasasanak-vizsgalatara-kidolgozott-meixner-olvasolap-sztenderdizalasanak-elso-eredmenyei.html

Snyder, J., \& Krumhansl, C. L. (2001). Tapping to ragtime: Cues to pulse finding. Music Perception: An Interdisciplinary Journal, 18(4), 455-489.

Steinbrink, C., Knigge, J., Mannhaupt, G., Sallat, S., \& Werkle, A. (2019). Are temporal and tonal musical skills related to phonological awareness and literacy skills? - Evidence from two cross-sectional studies with children from different age groups. Frontiers in Psychology, 10(Mar), 1-16. https://doi.org/10.3389/fpsyg.2019.00805

Surányi, Z., Csépe, V., Richardson, U., Thomson, J. M., Honbolygó, F., \& Goswami, U. (2009). Sensitivity to rhythmic parameters in dyslexic children: A comparison of Hungarian and English. Reading and Writing, 22(1), 41-56. https://doi.org/10.1007/s11145-007-9102-x

Thompson, E. C., White-Schwoch, T., Tierney, A., \& Kraus, N. (2015). Beat Synchronization across the Lifespan: Intersection of Development and Musical Experience. PLOS ONE, 10(6), e0128839. https://doi.org/10.1371/journal.pone.0128839

Todd, N. P. M., \& Lee, C. S. (2015). The sensory-motor theory of rhythm and beat induction 20 years on: a new synthesis and future perspectives. Frontiers in Human Neuroscience, 9, 444. https://doi.org/10.3389/fnhum.2015.00444

Török, T., \& Hódi, Á. (2015). A fonológiai tudatosság fejlôdése és szövegértéssel való kapcsolata az általános iskola elsố négy évfolyamán a szocioökonómiai státusz tükrében. Magyar Pszichológiai Szemle, 70(4), 807-826.

Ullman, M. T., \& Pierpont, E. I. (2005). Specific language impairment is not specific to language: The procedural deficit hypothesis. Cortex, 41(3), 399-433.

Van Noorden, L., \& De Bruyn, L. (2009). The development of synchronization skills of children 3 to 11 years old. Proceedings of ESCOM-7th Triennial Conference of the European Society for the Cognitive Sciences of Music. Jyväskylä, Finland: University of Jyväskylä.

Van Noorden, L., \& Moelants, D. (1999). Resonance in the perception of musical pulse. International Journal of Phytoremediation, 21(1), 43-66. https://doi.org/10.1076/jnmr.28.1.43.3122

Winkler, I., Háden, G. P., Ladinig, O., Sziller, I., \& Honing, H. (2009). Newborn infants detect the beat in music. Proceedings of the National Academy of Sciences, 106(7), 2468-2471. https:// doi.org/10.1073/pnas.0809035106

Wohlschläger, A., \& Koch, R. (2000). Synchronization error: An error in time perception. In P. Desain \& L. Windsor, Rhythm perception and performance (pp. 115-127). Lisse, The Netherlands: Swets and Zeitlinger.

Wolff, P. H. (2002). Timing precision and rhythm in developmental dyslexia. Reading and Writing, 15(1/2), 179-206. https://doi.org/10.1023/A:1013880723925

Wong, P. C. M., Skoe, E., Russo, N. M., Dees, T., \& Kraus, N. (2007). Musical experience shapes human brainstem encoding of linguistic pitch patterns. Nature Neuroscience, 10(4), 420-422. https://doi.org/10.1038/nn1872

Woodruff Carr, K., White-Schwoch, T., Tierney, A. T., Strait, D. L., \& Kraus, N. (2014). Beat synchronization predicts neural speech encoding and reading readiness in preschoolers. Pro- 
ceedings of the National Academy of Sciences of the United States of America, 111(40), 14559-14564. https://doi.org/10.1073/pnas.1406219111

Yang, J., Ouyang, F., Holm, L., Huang, Y., Gan, L., Zhou, L., et al. (2020). Tapping ahead of time: its association with timing variability. Psychological Research, 84, 343-351. https://doi. org/10.1007/s00426-018-1043-2

Zentner, M., \& Eerola, T. (2010). Rhythmic engagement with music in infancy. Proceedings of the National Academy of Sciences of the United States of America, 107(13), 5768-5773. https://doi. org/10.1073/pnas.1000121107

\title{
RHYTHMIC SYNCHRONIZATION AND ITS RELATION TO PHONOLOGICAL AWARENESS AND READING ACQUISITION
}

\author{
KERTÉSZ, CSABA - F. FÖLDI, RITA - HONBOLYGÓ, FERENC
}

A growing body of research supports the link between rhythmic abilities and the development of language and reading, while investigations carried out with Hungarian speaking children are sparse. The rhythmic abilities of 39 typically developing, 6-7 year old, Hungarian native-speaking children were assessed at the beginning of their first school year in three domains: rhythm reproduction, tapping to a regular musical beat, and unpaced tapping, using a digital test suitable for their age. At the end of the school year, children completed tests of phonological awareness and reading abilities. Both showed significant correlation with several indicators of the tapping tasks. Surprisingly however, rhythm reproduction did not predict either of them. Although the moderate sample size of our present study does not allow far-reaching conclusions, our findings are congruent with previous literature, and in addition to the need for further research, stresses the importance of early rhythmic activities.

Keywords: Sensorimotor synchronization, tapping to a beat, phonological awareness, reading

A cikk a Creative Commons Attribution 4.0 International License (https://creativecommons. org/licenses/by/4.0) feltételei szerint publikált Open Access közlemény, melynek szellemében a cikk bármilyen médiumban szabadon felhasználható, megosztható és újraközölhetô, feltéve, hogy az eredeti szerzố és a közlés helye, illetve a CC License 